\title{
PRESERVATION OF HEALTHY AND HARMONIOUS RESIDENTIAL AND WORK ENVIRONMENT DURING URBAN DEVELOPMENT
}

\author{
Sigitas MITKUS ${ }^{1 凶}$ and Olga Regina ŠOSTAK ${ }^{2}$ \\ 1 Department of Law, Vilnius Gediminas Technical University, Sauletekio al. 11, LT-10223 \\ Vilnius, Lithuania \\ E-mail: Sigitas.Mitkus@vgtu.lt \\ 2 Department of Law, Vilnius Gediminas Technical University, Sauletekio al. 11, LT-10223 \\ Vilnius, Lithuania \\ E-mail: Olga-Regina.Sostak@vgtu.lt
}

Received 14 May 2009; accepted 17 September 2009

\begin{abstract}
The article discusses densification of fully urbanised territories, which causes deterioration of living conditions for tenants of neighbouring houses (third parties) due to the negative impact of construction on local environment. Specifically, detection of fundamental right violations during territorial planning is in focus, because not only third parties but also future tenants of the house being constructed suffer loss of healthy and harmonious work and recreational environment as a direct result of such violations. A classifier of fundamental right violations during territorial planning was developed for that purpose. The judicial practice was analysed; persons authorised to contest environmental violations under the Law on Administrative Proceedings and the scope of their authorisation were determined.
\end{abstract}

KEYWORDS: Construction investment process; Urban development; Subjective right to safe, clean and healthy environment; Defence of third party rights; Classification of violations during territorial planning

\section{INTRODUCTION}

Some parts of most of our cities undergo intensive transformations related to commercialisation, land use and density of buildings (Bardauskienè 2007; Turskis et al., 2006; Zavadskas et al., 2004; Daunora, 2004; Kaganova et al., 2008; Lindgren and Castell, 2008). On one hand, it is a natural stage related to renovation of neglected valuable urban areas. Development of a national economy is impossible without construction: people use construction products, i.e. various buildings, to live, work and satisfy other social needs (Urbanavičienè et al., 2009). On the other hand, the course and outcomes of this stage reveal gaps within the renewal process. We are inclined to blame the drawbacks of laws which regulate urban planning and protection of visual identity (investors cannot always be expected to abandon their self-centred ends for the sake of urban values, etc.) (Dringelis, 2005; Vrubliauskas, 2005; Jakaitis, 2004; Petrušonis, 2004; Greater London Authority, 2003). Several examples in European cities show that development can embrace internal urban areas (McDonald 
et al., 2009; Kaklauskas et al., 2009). Currently, Lithuanian cities also witness concentrated development (Zavadskas et al., 2009; Vyzienè and Girgždys, 2009; Burinskienè, 2009; Jakaitis et al., 2009). It allows use of the existing infrastructure and abandoned urban territories. Such planning of internal areas leads to increased population density and cuts the size of green zones. Such planning also reduces the amount of used land and creates a lasting environment, the immensely dense population of which not always is able to function properly (Zavadskas et al., 2009). Implementation of sustainable development policy is one of the most complicated tasks and challenges facing the entire community. Planning of sustainable urban development must rest on systematic approach (Burinskienè and Rudzkienè, 2009; Lahdenperä, 2009; Majamaa et al., 2008; Banaitis and Banaitienè, 2007; Smid and Nieboer, 2008). Currently, intensive debates on longterm urban development take part worldwide, and one would think that compact/small cities is one of the best ways to implement long-term development (Greater London Authority, 2003; Turskis et al., 2006); however, we must assess the negative impact of construction on local environment and business. Whereas the construction process is long and complex, it needs special attention in already urbanised territories. We must assess the level of deterioration of living conditions (dust, noise, etc.) suffered by local people (third parties) during construction process (Vaišis and Januševičius, 2008; Baltrènas et al., 2008; Mitkus and Šostak, 2008a), as well as the level of deterioration after completion of the construction project (excessive population density, increased traffic intensity, fewer green areas, etc.) (Mickaitytè et al., 2008; Baltrènas et al., 2007a, 2007b, 2007c; Baltrènas and Morkūnienè, 2006; Baltrènas et al., 2006; Poszyler-Adamska and Czerniak, 2007; Vaitekūnas and Banaitytè, 2007).

On one hand, construction investment contributes to national economic growth and de- velopment extensively (Viteikienè and Zavadskas, 2007; Chen, 1996; Lewis, 2004; Miller et al., 2004; Yu and Lo, 2005; Ribeiro, 2008). On the other hand, there is the negative impact of construction which must be considered at project planning and contract signing stages (Herbsman et al., 1995; Wong and Yip, 2004; Mitkus, 2004a, 2004b; Mitkus, 2005).

One of the main goals of the article is to assess the possible negative impact of construction on environment in urbanised territories. It has been determined that social costs related to construction process have remarkable effect on social life. This aspect demands for additional attention, and management efficiency of such costs must be improved. Previous studies dealing with the impact of construction on environment mostly included calculation of work area costs (Chien et al., 2002; Kim et al., 2004). Traditional construction management practice excluded social costs from its calculations for several reasons. First of all, construction social costs are external costs of a construction project assumed by society and not by project participants, i.e. the owner or the contractor. Therefore, they are not shown in project estimates. Secondly, most social costs of construction projects are rather implicit than explicit, and the available methods do not facilitate their measurement. Thirdly, the bearer of social costs, i.e. society, not always is fully present in the process of project planning and management, and public benefits are often simply ignored (Yu and Lo, 2005; Visuomenès dalyvavimo teritoriju planavimo procese nuostatai, 2007; Lietuvos Respublikos teritoriju planavimo istatymas, 2004). Studies on calculation of costs related to the effect on environment and on business are scarce, even if some researchers deemed such costs important. The authors of this article came across a research made by $\mathrm{Yu}$ and Lo (2005), who developed a model which allows to calculate the degree of negative impact of a road construction project on local environment and business. Yu and Lo 
(2005) determined that daily social costs are 5.52 times bigger than construction project costs.

The research of Yu and Lo (2005) seeks to establish the time-dependent construction social costs (COSCO) model in order to calculate the negative impact of construction on local environment considering two aspects (the key categories of daily construction social costs):

1) Effect on environment: calculation of daily environment costs imposed on society by construction process (previous researchers have specified that costs of future construction mostly affect daily social life).

2) Effect on business: calculation of daily business loss caused by construction process (daily decrease of local business profits reflects business loss due to the construction process).

Other aspects, i.e. psychological, visual and aesthetic, were not included because of the difficulty to measure them.

Still, few studies attempted to calculate these costs. The time-dependent construction social costs (COSCO) model is developed in order to calculate/assess the emerging negative impact of future construction at the initial stage: while preparing a construction project. The suggested COSCO model is a general model which calculates daily social costs incurred on sites of active construction projects. A conclusion was made that the costs of effect on environment ignored by previous researchers make the biggest share of social costs. It is more difficult to calculate the costs of effect on environment because they account for relatively subjective loss. Yu and Lo (2005) stress the fact that implementation of air and noise pollution control in the legal system of Taiwan in 2004 , i.e. air pollution and similar taxes collected from sources of pollution (e.g. daily costs of noise pollution: fines paid by contractors for use of construction equipment), enabled calculation of the costs of the effect on environment. Such taxes (for air pollution and noise) facili- tate objective assessment of construction social costs related to the effect on environment.

This article aims to study the application peculiarities of the concept of healthy and harmonious residential and work environment in law and judicial practice of the Republic of Lithuania; to classify possible violations which occur during preparatory stages of construction and can affect third party rights to healthy and harmonious residential and work environment; to study problems faced while defending the said rights.

As stated above, construction processes in fully urbanised territories increase traffic intensity (both during construction and after completion of an investment project), which is one of the main air pollution sources. Recent decades saw people becoming more aware of the importance of environment, thus the effect on environment, i.e. hard waste, liquid waste, air pollution and noise, must be analysed more thoroughly.

\section{REVIEW OF FACTORS AFFECTING ENVIRONMENT POLLUTION}

The main sources of environment pollution are industrial companies and transport. The process of fuel burning (coal, oil, gas) is of particular importance (by the way, all industrial branches and means of transport consume fuel). Means of transport are one of the biggest polluters of environment in Lithuanian cities. Land vehicles pollute urban territories by exhaust gases, they are very dynamic and can penetrate all urban territories: residential and industrial districts, urban centres, territories of hospitals and sanatoriums, recreational areas (Petrovic et al., 2009). About 200 of different chemical compounds can be found in exhaust gases of transport. Life quality in a city much depends on functioning of the transport system (Jakimavičius and Burinskienè, 2009; Scherer, 2009). It not only empowers people, but also warrants thriving of local economy. Rising 
numbers of people living in cities (also due to construction in urbanised territories) increase population density per one square kilometre and, in turn, the traffic intensity. Constantly increasing traffic intensity has considerable negative impact on environment and human health, it causes deterioration of general quality of life. High levels of transport-related air pollution harm human health and contribute to increasing greenhouse effect (Kaklauskas et al., 2007). Vaitekūnas and Banaitytè (2007) noted that traffic jams inevitably force to search for ways to reduce air pollution. There are two ways to assess the negative impact of transport exhaust gases and the level of pollution: either through air pollution monitoring or through atmospheric dispersion modelling. Atmospheric, terrain, wind speed and direction conditions must be assessed for numerical modelling of car pollution emissions (Baltrènas et al., 2008; Vaitekūnas and Banaitytè, 2007).

Air pollution is both local and cross-border problem caused by certain exhaust pollutants, which alone or through chemical reactions have negative impact on environment and health. The effect of air pollution on built environment is many-sided, but its harm to health causes the biggest concerns (Thematic Strategy on air pollution, 2005). Air pollution affects people in various ways: can cause cancer, birth defects, eye disorders, respiratory disorders, increased sensitivity to viruses, increased cases of heart diseases. Polluted urban air can cause major health problems. Toxic substances may penetrate the body through digestive system and skin, may be inhaled into lungs and get directly into blood stream through wounds (Curtis et al., 2006).

Various pollutants harm almost all human organs. For example, sulphur dioxide $\left(\mathrm{SO}_{2}\right)$, carbon monoxide (CO), volatile organic compounds, nitrogen dioxides (NO) and particulate matter $(\mathrm{PM})$ are the main components of air pollution. Almost all of them occur due to fuel combustion and traffic.
We shall proceed by a brief discussion of the negative effect of air pollution components on human body. Sulphur dioxide $\left(\mathrm{SO}_{2}\right)$ is an air-born pollutant emitted during combustion process (usually combustion of fossil fuels containing sulphur compounds), as well as during processing of oil products and production of sulphuric acid. $\mathrm{SO}_{2}$ (sulphur dioxide) and $\mathrm{SO}_{3}$ (sulphur trioxide) are colourless gases with a specific smell. The effect of sulphur oxides on health depends on their concentration in the air. Sulphur oxides cause irritations, reflex cough and swelling of upper respiratory mucous membranes, they also irritate mucous membrane of eyes. The level of pollution with nitric oxides is the highest in the biggest cities of Lithuania, namely Kaunas, Vilnius and Klaipedda, but also in Mažeikiai (due to activities of "Mažeikių Nafta" and the nearby cement plant) (Kauno miesto aplinkos kokybès tyrimai, VšI, 2008; Kaklauskas et al., 2007).

Baltrènas et al. (2008) specifies that reduction of pollution is one of environmental priorities in our country. Air quality monitoring stations installed in Lithuanian cities and biggest industrial centres daily update information about pollution in Vilnius and Kaunas conurbations, as well as territories of the remaining area. It is the main method of air quality assessment. The information provided by air quality monitoring stations proves that concentration of particulate matter often exceeds the allowed limits in certain areas. Air quality is assessed through mathematical atmospheric dispersion modelling, as well as through analysis of dust sources and the main reasons behind dust concentration.

EU is highly concerned about environment preservation (Štreimikienė and Esekina, 2008). It is admitted that environment pollution has negative impact on human development, health and labour efficiency, and the negative outcomes cost billions of euros. In order to maintain health of most people, rational means for urban construction and planning, as 
well as for designing of street networks, must be foreseen, by-passes or highways for continuous traffic must be constructed, priority plans for public transport development must be formulated, buildings must be situated rationally in the territories, and the best means to reduce environment pollution and noise must be foreseen (Kaklauskas et al., 2007).

Construction process includes numerous sources of pollution: the entire traffic-related pollution and noise, dust, etc. Construction process is especially harmful to fully urbanised territories.

To maintain healthy and harmonious residential and work environment, not only rational transport systems must be designed, but also other requirements applicable to densification of urban territories must be followed. Failure to follow requirements applicable to densification of urban territories means, in general, failure to create healthy and harmonious residential and work environment, because, one way or another, such failure will cause additional air pollution and other negative effects on residential and work environment (fire safety, hygiene, landscape and other requirements will not be complied with). We shall proceed with analysis of requirements applicable to residential environment during densification of urbanised territories and with analysis of possibilities to defend the right to healthy and harmonious residential environment.

\section{DEFENCE OF THE RIGHT TO HEALTHY AND HARMONIOUS RESIDENTIAL AND WORK ENVIRONMENT: RELATION BETWEEN PRIVATE AND PUBLIC INTEREST}

The Law on Administrative Proceedings of the Republic of Lithuania (hereinafter LAP) (Lietuvos Respublikos administraciniu bylu teisenos istatymas, 2000) limits the right of natural persons to defend public interest. Therefore, it is essential to determine which type of interests, private or public, is violated in order to ascertain the right of third parties (tenants of neighbouring parcels, etc.) to personally defend the subjective right to healthy residential and work environment.

Key solutions of a construction investment project are approved during detailed territorial planning. Analysis of judicial practice related to validation of third party claims (third parties are persons not involved in construction investment process directly, i.e. owners and users of neighbouring parcels, communities of residential districts, etc.) in the process of detailed territorial planning and implementation of its solutions, when disputed acts violate their subjective rights directly related to their right to healthy and safe environment, shows that courts, in some cases, consider such endeavours as attempts to defend public interest instead of own subjective rights (Mitkus and Šstak, 2008). Moreover, courts rely on provisions of LAP Chapters 5 and 36 (Lietuvos Respublikos administraciniu bylų teisenos istatymas, 2000) and state that complainants are not within the category of persons that have a right to defend public interest. Let us analyse an example: in its Judgement of 24/10/2006 (Administrative Case No. $\mathrm{A}^{10}$ 1775/2006), the Lithuanian Supreme Administrative Court (hereinafter LSAC) stated that the complainant (Lampèdžiai Community Centre) had not been authorised to appeal to court for defence of public interest and rejected the complaint (The Supreme Administrative Court of Lithuania, 2006c).

The court heard this case and determined that the resolution No. T-157 of 24 March 2005 of the Council of Kaunas City Municipality had approved the detailed plan for a parcel of 2,322 sq. m located in Gintaro g. 9. The specified main purpose of land use: Land for Other Purposes; the specified way of land use: territory for commercial activities and small businesses (type: territory for construction, finishing and use of recreational and tourism 
information and leisure centres, concert halls, exhibitions, theatres and other commercial objects), as well as residential territory (type: territory for apartment buildings). The resolution of the Council of Kaunas City Municipality also specified the allowed height of buildings in the parcel of Gintaro g. 9: up to three storeys with penthouses. On 20 May 2005, the Division of Construction Permits and Infrastructure of the Urban Development Department of the Administration of Kaunas City Municipality issued the permit No. 38-3-GN256-246 to Kaminta UAB for construction of an apartment building in Gintaro g. 9, Kaunas. On 20 December 2005, the Division of Construction Permits and Infrastructure of the Urban Development Department of the Administration of Kaunas City Municipality issued the permit No. 38-3-GN256-246/1 to Kamintos Investicija $\mathrm{UAB}$ for construction of an apartment building in Gintaro g. 9, Kaunas.

The complainant, Lampèdžiai Community Centre, demanded from the Council of Kaunas City Municipality to annul the resolution of $24 / 03 / 2005$ and the construction permits issued by the municipal administration. The court of first instance rejected the complainant's claim. LSAC specified that anything of objective significance, value and importance to society or part thereof should be considered public interest. The complainant claimed that the future apartment house would damage the landscape and pollute visual environment thus damaging the protected natural landscape complex. These issues would be significant to the entire society. Therefore, the Lithuanian Supreme Administrative Court upheld the conclusion issued by the administrative court of first instance: the complainant appealed to court in order to defend public interest instead of its own subjective rights.

On 31/10/2001, the Republic of Lithuanian ratified Aarhus Convention (UNECE, 1998) which grants rights regarding access to information, public participation in decision mak- ing and access to justice in environmental matters. The Convention foresees a right of public organisations to appeal to administrative courts in order to defend environmental public interest if the effect on environment might be significant. Appendix I to the Convention lists types of activities which can affect environment seriously. It follows that a public organisation can seek justice defending environmental public interests only in cases of activities listed in this appendix. Construction of residential buildings is not in the list. Thus the administrative court of first instance came to a valid conclusion that, in this particular case, the complainant was not authorised to appeal to court to defend public interest and rejected the complaint justly (The Supreme Administrative Court of Lithuania, 2006c).

Lithuanian law has not yet defined the concept of Public Interest in legal acts, i.e. the legislator has not described the conception of public interest. Judicial practice deems that, referring to LAP (Lietuvos Respublikos administraciniu bylu teisenos istatymas, 2000), public interest generally should be treated as anything of objective significance, value and importance to society or part thereof, and a person's right to defend public interest in administrative proceedings is defined as a right of persons specified by laws to appeal to administrative court in cases specified by laws in order to defend anything of objective significance, value and importance to society or part thereof (The Supreme Administrative Court of Lithuania, 2004). Therefore, any administrative court must consider particular circumstances of a case and determine whether the subject matter of complaint defending public interest is objectively significant, important and valuable to society or part thereof. Obviously, a situation might occur when personal subjective right or legally protected interest overlaps, to some extent, with things significant, important and valuable not only to a particular person but also to society or part 
thereof, and a person, who brought his/her subjective right or legally protected interest for defence in court, would at the same time have a certain influence on protection of public interest. In such case, it cannot be claimed that these circumstances cause a person to lose his/her right to appeal to court in order to defend his/her subjective right or legally protected interest, because the laws do not stipulate for such cases (The Supreme Administrative Court of Lithuania, 2007; The Supreme Administrative Court of Lithuania, 2006a).

Lithuanian administrative courts which are authorised to settle disputes on validity of detailed territorial planning and the related construction permits had their chance to express their opinion on provisions of the said Convention and adopted yet narrower interpretation of the Convention than its logicallinguistic analysis would allow, let alone the possibility to apply the broad and thoughtful explanation of provisions of this Convention relating it to general environmental matters. Implementation of Aarhus Convention embodies expectations of Lithuanian society, which seeks to protect its social environment from unrestricted construction (Zavadskas et al., 2004). The Convention (UNECE, 1998) regulates three opportunities of legal society: access to environmental information, participation in environmental decision-making, access to justice in environmental matters.

Analysis of the provisions of Aarhus Convention (UNECE, 1998) shows that not only public organisations which deal with environmental matters and act under requirements of national legislation but also natural persons have a right to defend public interest appealing to administrative courts in matters related to natural elements: air, atmosphere, water, soil, land, landscape, natural objects, biological variety (The Supreme Administrative Court of Lithuania, 2006b). Whereas Lithuanian courts retained narrower interpretation of the concept of environment than Aarhus Conven- tion (UNECE, 1998) and the attending EU legal acts (Directive 2003/4/EC, 2003; Directive 2003/35/EC, 2003), it was necessary to revise the grounds of claims submitted by persons whose right to healthy and safe environment had been violated. Such claims, common in EU countries, are yet trying to penetrate the Lithuanian legal system.

Although judicial practice sticks to the approach that public interest does not deny and is not in contraposition with individual interest of a member of society (or part thereof), it is, however, intended to consider various aspects of defence of rights and accumulate and balance respective interests of all community members (or part thereof). Courts deem that failure to comply with the requirements applicable to construction of a residential building during its construction limits the subjective right to healthy and clean environment of people who live in the neighbourhood (The Supreme Administrative Court of Lithuania, 2007). Such judicial interpretation determined formulation of the concept of healthy and harmonious residential and work environment in Lithuanian judicial practice and allowed to specify persons authorised to defend environmental public interest and the scope of their authorisation.

In general, the judicial practice related to this matter was formulated in the LSAC Judgement (Administrative Case No. $\mathrm{A}^{3}$ 64/07) of 19/01/2007 (The Supreme Administrative Court of Lithuania, 2007), which determined that the complainant (natural person T. Z.) had had a right to appeal to court in order to defend public interest and annulled the resolution of the Council of Vilnius City Municipality (approving the detailed plan) and the construction permit.

In this administrative case, the complainants asked the court to defend their rights to healthy and harmonious residential, work and recreational environment, which, in their opinion, had been violated. The court deter- 
mined that the complainants are tenants of houses (confidential data) located in the land plot neighbouring with the disputed parcel (the parcel determined by the resolution of 07/06/2001 on approval of the detailed plan contested by the complainants; the construction permit issued on 01/03/2005 for construction in the parcel was also contested by the complainants). The court specified that claims of the complainants prove that their subjective right to demand annulment of contested resolutions is based on their attempt, acting as members of interested society, to defend their violated right to healthy and harmonious residential, work and recreational environment and their right to participate in preparation of the contested detailed plan. The complaints also specified that the designed house (under construction) is in the territory of the existing public playground and is too large; future tenants of this house will use common residential area and infrastructure; construction and completion of the house may negatively affect their (complainants') access to national and local roads and streets, as well as protection against noise and vibration. The court specified that the arguments provided by the complainants and the actual circumstances are related not only to their subjective rights which they seek to defend but also to public interest; and LAP (Lietuvos Respublikos administraciniu bylu teisenos istatymas, 2000) stipulates specific procedure for the defence of the latter (meaning that a specifically defined group of persons is authorised to bring such interest to court for defence). The complainants are not within the category of persons authorised to defend public interest (LAP Ch. 5, Part 3, Point 3; Ch. 56, Part 1) (Lietuvos Respublikos administraciniu bylu teisenos istatymas, 2000). Therefore, the court came to a conclusion that, before hearing this case, it should determine the extent to which the claims and arguments submitted by the complainants belong to the institute of public interest defence and the extent of their direct relation to specific legal rights and legally protected interests of the complainants. In one case (if it is defence of public interest), the complaint must be rejected because it is filed by persons without authority to defend public interest. In other case (if it is violation of specifically defined rights or legally protected interests concerning only the complainants), the violated rights or legally protected interests can/must be defended in one of the ways specified in $\underline{L A P}$ (Lietuvos Respublikos administraciniu bylu teisenos istatymas, 2000) Chapter 88. (The Supreme Administrative Court of Lithuania, 2007).

The court admitted to possible overlap of private legal interests and public interests. Thus a situation might occur when illegal act or omission would violate both types of interests at the same time. In such case, both a natural person whose right or legal interest are violated and an entity which has a legal right and/or obligation to defend public interest can appeal to court for defence. The complainants demanded the court to defend their allegedly violated rights to healthy and harmonious residential, work and recreational environment. Legal norms set by the Constitution and the Law on Environment Protection of the Republic of Lithuania and the analysis of the doctrine of the Constitutional Court show that environment protection is a constitutional principle, which respectively determines legal regulation in this area of particular importance to society (Lietuvos Respublikos konstitucija, 1992; Lietuvos Respublikos aplinkos apsaugos istatymas, 1992). On one hand, the Constitution obliges the state and its citizens to ensure and take care of environment protection, including preservation of healthy and harmonious environment (Lietuvos Respublikos konstitucija, 1992). On the other hand, the Constitution grants a right to healthy and clean environment for everyone (Lietuvos Respublikos konstitucija, 1992). These matching rights and obligations are regulated in de- 
tail by laws and attending legal acts, which, however, cannot contradict Constitutional provisions and cannot distort their goal and meaning. It should be noted that preservation of healthy and clean environment is a public interest. At the same time, the right to healthy and clean environment is a subjective material right of each individual, and it can be defended in court. Consequently, public interest embraces private legal interest in this particular case; they are not opposites. Analysis of laws shows that the complainants have subjective material rights both in the area of environment protection (right to healthy and clean environment) and in the area of territorial planning (right to participate in planning). These areas also belong to public interest and are closely interrelated. Thus public and private interests coincide in this situation (The Supreme Administrative Court of Lithuania, 2006a).

In this case, the court determined that the complainant T. Z. had had a subjective right to healthy and harmonious residential and work environment. The court specified that environment is usually perceived as the entire set of interrelated elements functioning in nature (upper and deep ground layers, air, water, soil, flora, fauna, organic and inorganic substances, anthropogenic components), as well as natural and anthropogenic systems which unite them. Thus proofs were provided in the case that the building which is being constructed near the place of residence of T. Z. is too high and provisions of the construction regulation are not complied with; therefore, it violates the subjective right of the complainant T. Z., i.e. during construction of a new building changes of the environment in the place where she lives and works must meet the requirements stipulated by legal norms of construction (The Supreme Administrative Court of Lithuania, 2007).

The next chapter analyses what requirements must be maintained in order to prevent violation of third party rights to healthy and harmonious environment.

\section{CLASSIFICATION OF VIOLATIONS OF THIRD PARTY RIGHTS}

Although it would seem that compact/ small cities is one of the best ways to implement long-term development, such practice also brings about harmful effect of urban densification. Expansion of construction business and penetration of construction companies into already settled and urbanised territories often brings about violation of third party rights, i.e. densification of buildings in urban territories often means deterioration of living conditions for tenants of neighbouring houses (third parties) due to the negative impact of construction on local environment (Šostak and Kutut, 2009). STR "Residential Buildings" (STR, 2004) determines the following provisions related to the effect of a building and its environment planned in a parcel on third parties: use and maintenance of the entire constructed residential building with fixtures should not cause deterioration of living and work conditions of third parties compared to the conditions available before the construction. If, for objective reasons, conditions cannot remain unchanged, such changes cannot exceed the limits set by the requirements of normative construction technical documents and normative documents regulating building safety and purpose.

STR "Residential Buildings" (STR, 2004) specifies that two aspects related to protection of valid third party interests must be considered while designing a residential building and its fixtures:

1) influence of third parties on the designed building and its environment in the parcel, as well as on tenants of the building;

2) effect of the entire designed building and its environment in the parcel on third parties.

The regulating conditions are as follows: the entire building and its environment in the parcel must be constructed following the design documentation and used for the speci- 
fied purpose; the design documentation must be prepared in the manner which shall foresee that construction of the residential building, landscaping, construction of the fixtures, access paths and ways, underground and overground construction/laying of engineering systems will not cause deterioration of current technical condition of third party buildings and will not create preconditions for emergence of factors which could later (during use) cause deterioration of technical conditions of such buildings; the design documentation must foresee free access of third persons to national and local roads and streets; solutions of the design documentation cannot limit possibilities to use engineering networks; location of solutions of the design documentation, including the residential building, fixtures and green areas, cannot reduce size of third party parcels and apartment insolation; solutions of the design documentation must consider and cannot damage third party fire protection measures and systems, and must preserve their functional features; the residential building, its fixtures and the parcel must be designed in such way that their use, as well as levels of noise, vibration, electric interference and dangerous radiation caused by activities allowed in the building, would not have negative effect on third persons; solutions of the design documentation must protect natural and cultural values located in the parcel.

A situation when third party rights are violate puts both third parties and participants of a construction investment project at a disadvantage, because it might, on one hand, cause unsanctioned deterioration of third party living and work conditions. On the other hand, violations of third party rights during construction planning might have effect on implementation of the investment project, because all solutions violating third party rights also violate provisions of normative legal acts and may be contested as stipulated by LAP (Lietuvos Respublikos administracinių bylų teisenos istatymas,
2000). Construction investment process is long and complex; it demands large amounts of financial, intellect and other resources. Should a judicial dispute interfere with the process, an investor might suffer huge loss and the implementation might be postponed for indefinite period. Litigation may even take several years (The Supreme Administrative Court of Lithuania, 2007). Therefore, investors are most interested to avoid any legal disputes and should pay more attention to their prevention. This fact makes issues related to defence of violated third party rights more relevant.

The key solutions of a construction investment project are approved during detailed territorial planning. Third party rights can be violated during detailed planning by approving illegal solutions. Whereas the requirements for solutions of detailed plans are specified in most legal acts (construction technical regulations, etc.), it is expedient to classify possible violations of third party rights at this stage in order to avoid the violations. Legal sources regulating third party rights and their protection were analysed for that purpose, such as STR 2.02.01:2004 "Residential Buildings," STR 2.02.09:2005 "Detached Residential Buildings," STR 1.01.07:2002 "Simple (temporary among them) Buildings," etc.; the requirements (hygiene, fire safety and other requirements for residential buildings and their parcels) applicable to solutions of detailed plans were also analysed, sorted and structured (Mitkus, 2007).

Possible violations of third party rights during construction planning were classified in order to avoid or considerably reduce violations of third party rights in the process of detailed planning and in order the planned construction in urbanised territories would meet the requirements of normative documents to the maximum; this classification is sufficiently comprehensible not only to construction experts but also to people within local community, thus it may make third parties aware about violations of their rights. It may also help to 
avoid the following problem: debarring of society from decision-making in urban development matters (see Figure 1).

The classification in Figure 1 shows four groups of possible violations of third party rights: fire safety requirements, built territory requirements, insolation requirements and other requirements. This classification shows the most frequent violations based on the data obtained through research performed by the authors.

We shall continue with detailed analysis of some requirements applicable to solutions of detailed plans.

\subsection{Ensured access of fire-fighting equipment}

Adequate access to constructed residential buildings is the key condition to maintain healthy and harmonious residential and work environment for third persons. STR "Residential Buildings" (STR, 2004) sets the following imperatives:

- Each residential (detached, apartment or semi-detached) building must have adequate access for fire-fighting equipment.

- Access roads and paths of buildings must ensure the fire crew access to at least one window of each apartment, to apart-

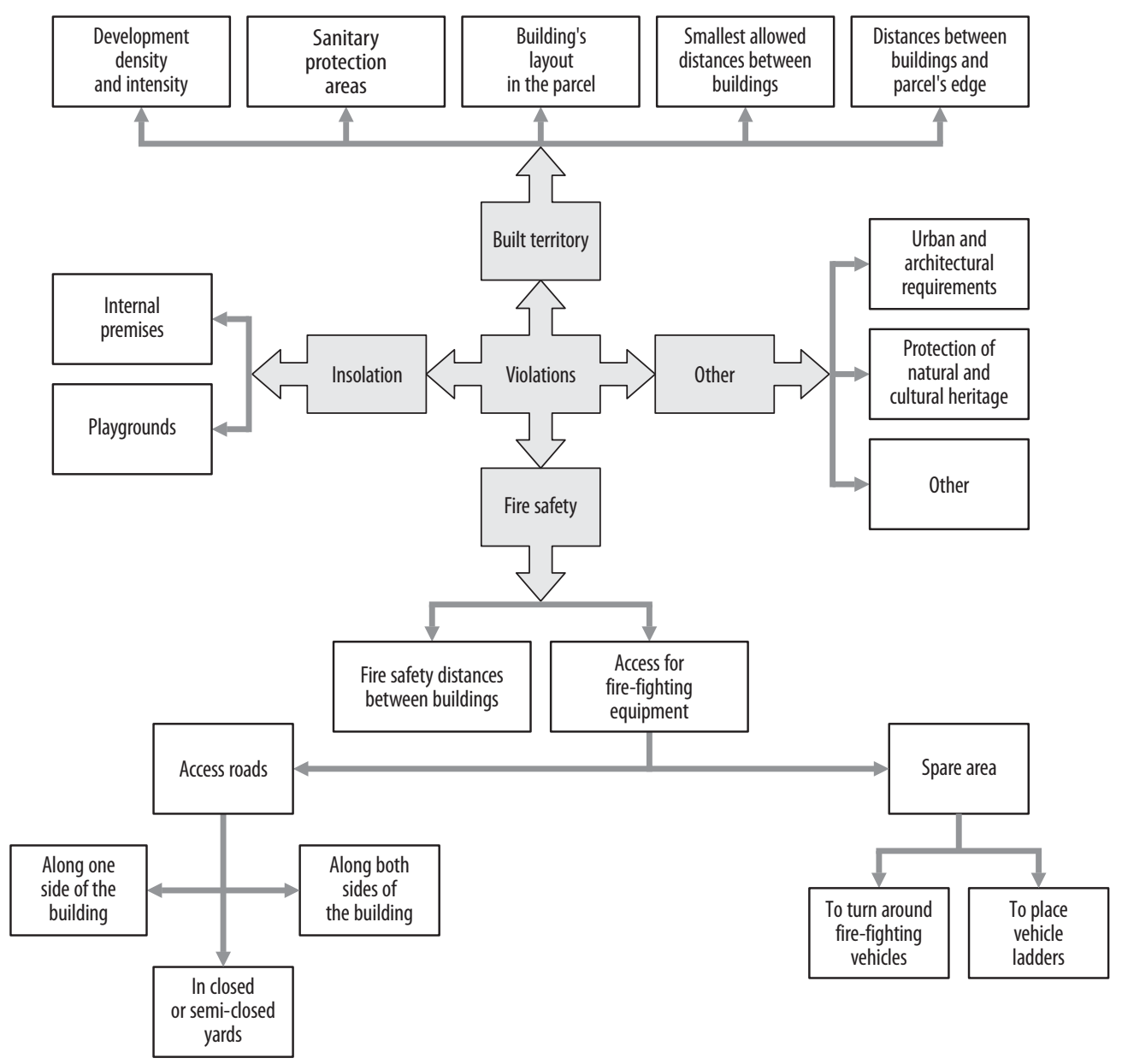

Figure 1. Classification of possible violations of third party rights during territorial planning 
ments, to fire-fighting elevator, to premises with electricity and gas inlets and to control rooms of fire-fighting systems.

- For buildings (detached, apartment or semi-detached) of four storeys and smaller, access roads for fire-fighting equipment may be at a distance of $25 \mathrm{~m}$ from the buildings. Four-storey buildings must have access roads for placement of firefighting vehicle ladders.

- Apartment buildings of four storeys and higher must have access roads for firefighting equipment along both sides and auxiliary areas for placement of firefighting vehicle ladders.

- For five-storey apartment buildings, access roads may be only along one side, if it ensures access to all apartments through windows on this side and if products used for decoration of building façades at least fall within the class A2-sl, d0 of reaction to fire.

- For placement of vehicle ladder, a lane of at least $6 \mathrm{~m}$ in width or a site of $16 \times 16 \mathrm{~m}$ must be constructed at a distance of 7-16 $\mathrm{m}$ from building considering the height of an apartment house and technical features of a vehicle.

- Trees and other obstacles cannot block access between the building and the lane intended for placement of vehicle ladder.

- Access roads and sites for fire-fighting vehicles must be always empty; special road signs or fencings (height up to 30 $\mathrm{cm}$ ) may be used for that purpose.

- To access façades, fire-fighting vehicles are allowed to use special roofs of stylobates and annexes, which are designed to bear the load of fire-fighting vehicles.

- Closed and semi-closed yards must have access roads for fire-fighting vehicles, if respective apartment buildings have more than three storeys or yard's external outline is longer than $800 \mathrm{~m}$. Arches must be at least $3.5 \mathrm{~m}$ in width and
$4.25 \mathrm{~m}$ in height. If an access road leads to a cul-de-sac, it must have a site of at least $12 \times 12 \mathrm{~m}$ for fire-fighting vehicles to turn around.

\subsection{Violations of built territory}

Requirements for built territories are violated when the smallest allowed distances between buildings or to parcel's edge are not ensured, when requirements on density and intensity of built territory are violated, sanitary protection areas are not determined, etc.

Chapter 3 of this article proves that judicial practice admits to violation of the personal right to healthy and harmonious environment if too many buildings are constructed (excessive density and intensity) or some mandatory areas are not planned in the neighbouring parcel. Chapter 23 of the Law on Territorial Planning of the Republic of Lithuania (Lietuvos Respublikos teritoriju planavimo istatymas, 2004) sets the following mandatory way of territorial management and use to be included in detailed plans: purpose of territory (parcel) and/or its type; allowed height of buildings; allowed density of the development in the parcel; allowed intensity of the development in the parcel; the area, boundaries or the line for construction of buildings; utility or local engineering networks, supply of engineering services to the territory (parcel) and communication corridors; arrangement of the transport system; servitutes. The Law on Territorial Planning of the Republic of Lithuania Lietuvos Respublikos teritoriju planavimo istatymas, 2004) gives the following definitions:

- Intensity of the development shall mean the ratio of the sum of the total area of the ground premises of all buildings and the area of the parcel.

- Density of the development shall mean the ratio of the built area established according to the boundaries of external walls and the total area of the land parcel. 
The density and intensity of the development cannot violate the requirements on density and intensity specified in the detailed plan and other normative documents.

Construction, refurbishment and repair of residential building, its fixtures and engineering networks cannot make negative impact on the neighbouring parcel and its buildings. STR "Residential Buildings" (STR, 2004) imperatively states that building's parcel is intended for construction of a building, access paths and roads, as well as for recreational and household needs of its tenants. Any parcel must at least have the following parts (areas): the area for the building; access paths and roads to the building; car parking lot; green areas with playgrounds and sports fields, recreational areas for elderly and disabled people (green areas must occupy at least $25 \%$ of free area in the parcel); bicycle parking lot; place for temporary storage of household waste; and structures for engineering systems (electric transmission substations, etc). STR "Residential Buildings" (STR, 2004) mandates a distance of at least $3 \mathrm{~m}$ between residential buildings and the edges of the parcel if buildings are of one or two storeys. Distances between buildings are regulated by fire safety and insolation requirements.

Insolation is the amount of direct sunlight falling on territories, buildings and into rooms. Insolation requirements are violated when rooms of buildings get less insolation than required or insolation of playgrounds is lower than the norms. STR "Residential Buildings" (STR, 2004) mandates that multi-storey residential buildings must be arranged in the following manner: ensure compliance with insolation requirements for rooms and playgrounds; prevent blocking of natural lighting of rooms; and comply with requirements on natural lighting of rooms.

STR "Residential Buildings" (STR, 2004) mandates that requirements to other newly constructed or reconstructed buildings are considered complied with if the distance from the blocking building is at least equal to its height or bigger (see Figure 2 and 3); the distances may be smaller if a visual angle of at least $60^{\circ}$ will be ensured for windows of the blocked building on the horizontal plane (see Figure 2 and 3$)$.

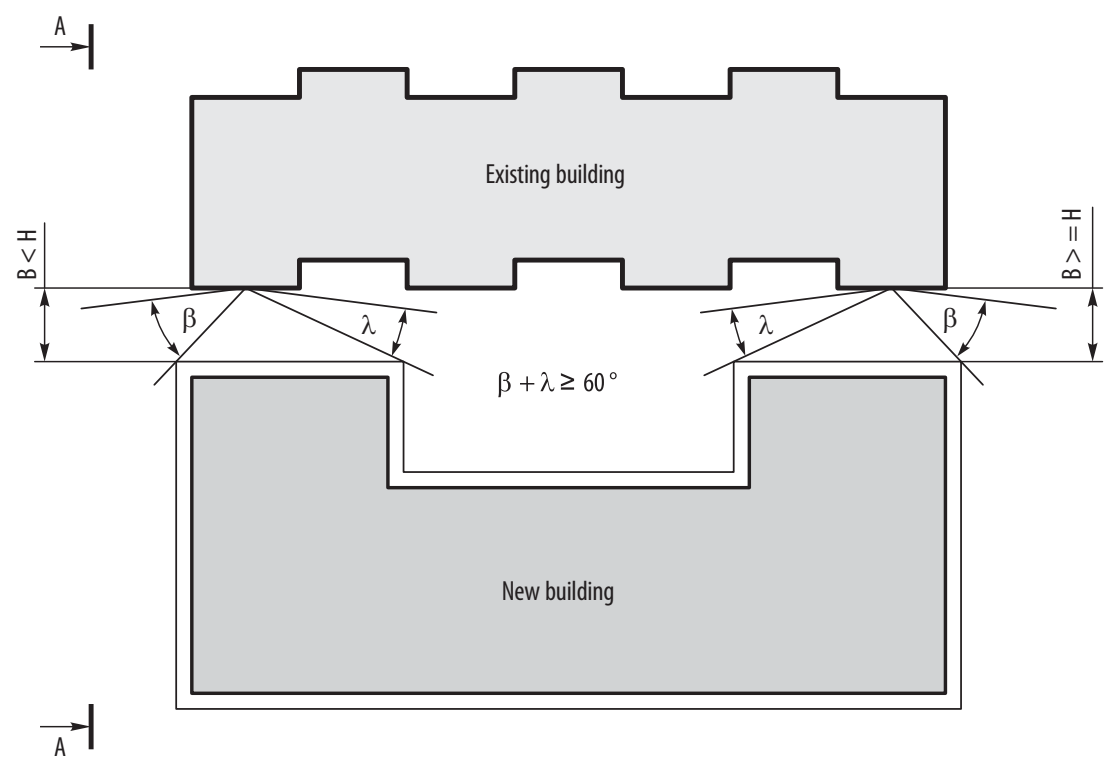

Figure 2. Plan 


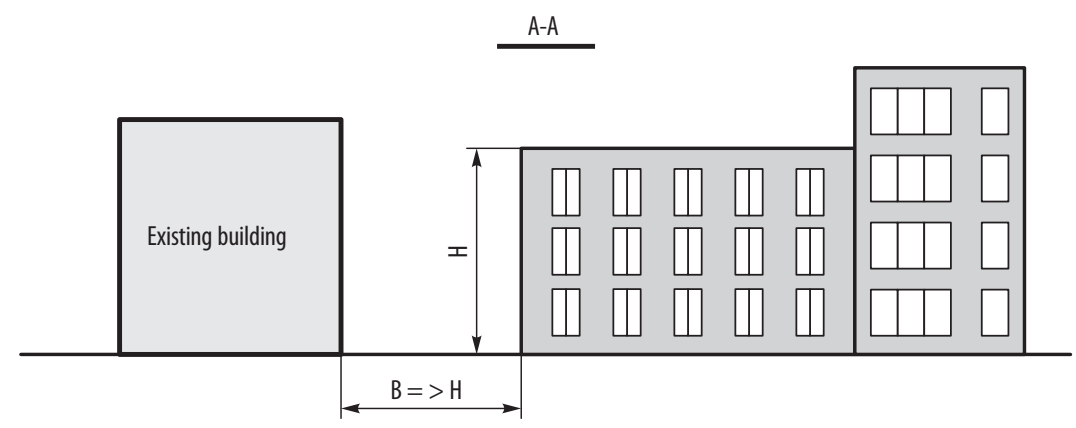

Figure 3. Cross-section A-A

\section{CONCLUSIONS}

1. Densification of urbanised territories often affects third party rights to healthy and harmonious residential and work environment. This effect must be assessed in the construction investment process as early as possible; the authors think these aspects must be considered as early as during territorial planning. Assessment of this effect must consider two aspects of negative impact of construction on local environment: effect on environment (calculation of daily environment costs imposed on society by construction process) and effect on business (calculation of daily business loss caused by construction process).

2. The main source of environment pollution is transport. Construction in fully urbanised territories causes increased traffic intensity, which is one of the main air pollution sources. Rising numbers of people living in cities (also caused by construction in urbanised territories) increase population density, which means increased traffic intensity. Inappropriate densification of urbanised territories contributes to irrational development of the transport system; it indirectly causes increased environment pollution and violates third party rights to healthy and harmonious residential and work environment.

3 . The analysis of judicial practice of the Republic of Lithuania proved the lack of unani- mous approach to defence of third party rights to healthy residential and work environment. In some cases, courts interpreted defence of such right as defence of public interest and, based on this, rejected complaints of third parties related to their right to healthy and harmonious environment. However, later courts admitted that private legal interest and public interest might overlap. Then a situation might occur when illegal act or omission violates both interests at the same time. In such case, both a natural person whose right or legal interest are violated and an entity which legally has a right and/or obligation to defend public interest can appeal to court for defence. The authors think that the current legal basis must be amended granting rights not only to public organisations dealing with environmental matters and acting under the requirements of national legislation but also to natural persons to defend public interest before administrative courts in matters related to natural elements: air, atmosphere, water, soil, land, landscape, natural objects, biological variety, etc.

4. Possible violations of third party rights during construction planning were classified; the classification is sufficiently comprehensible not only to construction experts but also to members of local community, it may make third persons aware of their violated rights. 


\section{REFERENCES}

Baltrènas, P. and Morkūnienè, J. (2006) Investigation of particulate matter concentration in the air of Žverynas district in Vilnius, Journal of Environmental Engineering and Landscape Management, 14(1), pp. 23-30.

Baltrènas, P., Kvasauskas, M. and Fröhner, K.D. (2006) Influence of stevedoring operations of liquid and powdery fertilizers at Klaipeda state seaport on the ambient air quality, Journal of Environmental Engineering and Landscape Management, 14(2), pp. 59-68.

Baltrènas, P., Fröhner, K.D. and Puzinas, D. (2007a) Jūru uosto įrenginiu triukšmo sklaidos įmonès ir gyvenamojoje teritorijoje tyrimai [Investigation of noise dispersion from seaport equipment on the enterprise territory and residential environment], Journal of Environmental Engineering and Landscape Management, 15(2), pp. 85-92. (In Lithuanian)

Baltrenas, P., Butkus, D., Nainys, V., Grubliauskas, R. and Gudaitytè, J. (2007b) Triukšmo slopinimo sienelès efektyvumo ịvertinimas [Efficiency evaluation of a noise barrier], Journal of Environmental Engineering and Landscape Management, 15(3), pp. 125-134. (In Lithuanian)

Baltrènas, P., Fröhner, K.D. and Pranskevičius, M. (2007c) Investigation of seaport air dustiness and dust spread, Journal of Environmental Engineering and Landscape Management, 15(1), pp. 15-23.

Baltrènas, P., Morkūnienė, J. and Vaitekūnas, P. (2008) Mathematical simulation of solid particle dispersion in the air of Vilnius city, Journal of Environmental Engineering and Landscape Management, 16(1), pp. 15-22. doi:10.3846/1648-6897.2008.16.15-22

Banaitis, A. and Banaitienè, N. (2007) Development of a rational housing model: The Lithuanian case, International Journal of Environment and Pollution, 30(3/4), pp. 430-442. doi:10.1504/IJEP.2007.014820

Bardauskienè, D. (2007) Ekspertinių vertinimu taikymas rengiant miesto bendraji plana [The expert's estimates application in the preparation of city general plan], Technological and Economic Development of Economy, 13(3), pp. 223-236. (In Lithuanian)

Burinskienè, M. (2009) New methodology for sustainable development towards sustainable transportation system, Technological and Economic Development of Economy, 15(1), pp. 5-9. doi:10.3846/1392-8619.2009.15.5-9
Burinskienė, M. and Rudzkienė, V. (2009) Future insights, scenarious and expert method application in sustainable territorial planning. Technological and Economic Development of Economy, 15(1), pp. 10-25. doi:10.3846/1392-8619.2009.15.10-25

Chen, J.J. (1996) The impact of public construction investment upon special economic zones - the Chinese experience, Construction Management and Economics, 14(2), pp. 175-182. doi:10.1080/014461996373610

Chien, S., Tang, Y. and Schonfeld, P. (2002) Optimizing work zones for two-lane highway maintenance projects, Journal of Transportation Engineering -ASCE, 128(2), pp. 145-155. doi:10.1061/(ASCE)0733-947X(2002)128:2(145)

Curtis L., Rea W., Smith-Willis P., Fenyves E. and Pan, Y. (2006) Adverse health effects of outdoor air pollutants, Environment International, 32(6), pp. 815-830. doi:10.1016/j.envint.2006.03.012

Daunora, Z.J. (2004) Istorinių miestų vizualinio ivaizdžio plètojimo klausimu [Issues of visual image development in historical cities], Town Planning and Architecture, 28(4), pp. 144-150. (In Lithuanian)

Directive 2003/4/EC (2003) Directive 2003/4/ EC of the European Parliament and of the Council of 28 January 2003 on public access to environmental information and repealing Council Directive 90/313/EEC. [Online] The European Parliament and the Council of the European Union. Available at: http:// eur-lex.europa.eu/LexUriServ/LexUriServ. do?uri=CELEX:32003L0004:EN:HTML [accessed 22 October 2007].

Directive 2003/35/EC (2003) Directive 2003/35/ EC of the European Parliament and of the Council of 26 May 2003 providing for public participation in respect of the drawing up of certain plans and programmes relating to the environment and amending with regard to public participation and access to justice Council Directives 85/337/EEC and 96/61/EC. [Online] The European Parliament and the Council of the European Union. Available at: http://eur-lex.europa.eu/LexUriServ/LexUriServ.do?uri=CELEX:32003L0035:EN:NOT [accessed 22 October 2007]

Dringelis, L. (2005) Miesto viešosios erdvės: pokyčiu tendencijos ir savitumo išsaugojimas. [Public Urban Areas: trends of changes and preservation of peculiar features], Town Planning and Architecture, 29(1), pp. 50-53. (In Lithuanian) 
Greater London Authority (2003) Housing for a Compact City. Greater London Authority Architecture and Urbanism Unit.

Herbsman, Z.J., Chen, W.T. and Epstein, W.C. (1995) Time is money: innovative contracting methods in highway construction, Journal of Construction Engineering and ManagementASCE, 121(3), pp. 273-281. doi:10.1061/(ASCE)0733-9364(1995)121:3(273)

Jakaitis, J. (2004) Neformalaus veikimo veiksniu itaka urbanistinei raidai [Influence of factors of informal activities on urban development], Town Planning and Architecture, 18(3), pp. 132-143. (In Lithuanian).

Jakaitis, J., Paliulis, N. and Jakaitis, K. (2009) Aspects of the national urban policy management under conditions of integrated planning, Technological and Economic Development of Economy, 15(1), pp. 26-38. doi:10.3846/1392-8619.2009.15.26-38

Jakimavičius, M. and Burinskienè, M. (2009) A GIS and multi-criteria-based analysis and ranking of transportation zones of Vilnius city, Technological and Economic Development of Economy, 15(1), pp. 39-48. doi:10.3846/1392-8619.2009.15.39-48

Kaganova, O., Akmatov, A. and Undeland, C. (2008) Introducing more transparent and efficient land management in post-socialist cities: lessons from Kyrgyzstan, International Journal of Strategic Property Management, 12(3), pp. 161181. doi:10.3846/1648-715X.2008.12.161-181

Kaklauskas, A., Zavadskas, E.K., Vainiūnas, P., Jonaitis, V. and Stragys, V. (2007) Lietuvos statybu 2007-2030 vizija ir strategija. Gyvenimo kokybė [A vision and strategy for Lithuanian construction 2007-2030. Quality of life]. Lietuvos nacionalinè statybu technologiju platforma, pp. 30-38. (In Lithuanian).

Kaklauskas, A., Zavadskas, E.K. and Šaparauskas, J. (2009) Conceptual modelling of sustainable Vilnius development, Technological and Economic Development of Economy, 15(1), pp. 154-177. doi:10.3846/1392-8619.2009.15.154-177

Kauno miesto aplinkos kokybès tyrimai, VšI (2008) Pagrindiniai atmosferos teršalai [Main atmosphere pollutants]. [Online] Kauno miesto aplinkos kokybès tyrimai, Všt. Available at: http://193.219.38.28/Apie_tersalus.html [accessed 13 February 2008] (In Lithuanian)

Kim, E., Jha, M.K. and Schonfeld, P. (2004) Intersection construction cost functions for alignment optimisation, Journal of Transportation Engineering-ASCE, 130(2), pp. 194-203. doi:10.1061/(ASCE)0733-947X(2004)130:2(194)
Lahdenperä, P. (2009) Phased multi-target areal development competitions: algorithms for competitor allocation, International Journal of Strategic Property Management, 13(1), p. 1-22. doi:10.3846/1648-715X.2009.13.1-22

Lewis, T.M. (2004) The construction industry in the economy of Trinidad \& Tobago, Construction Management and Economics, 22(5), pp. 541549. doi:10.1080/0144619042000190234

Lietuvos Respublikos administraciniu bylu teisenos istatymas (2000) [The Law on Administrative Proceedings of the Republic of Lithuania], Vilnius, Valstybès žinios, 200010 11, Nr. 852566. (In Lithuanian)

Lietuvos Respublikos aplinkos apsaugos istatymas (1992) [The Law on Environment protection of the Republic of Lithuania], Vilnius, Valstybes žinios, 1992, Nr. 5-75. (In Lithuanian).

Lietuvos Respublikos konstitucija (1992) [The Constitution of the Republic of Lithuania], Vilnius, Valstybès žinios, 1992, Nr. 33-1014. (In Lithuanian)

Lietuvos Respublikos teritoriju planavimo įstatymas (2004) [The Law on Territorial Planning of the Republic of Lithuania], Vilnius, Valstybes žinios, 200402 07, Nr. 21-617. (In Lithuanian)

Lindgren, T. and Castell, P. (2008) Open space management in residential areas - how it is organised and why, International Journal of Strategic Property Management, 12(3), pp. 141-160. doi:10.3846/1648-715X.2008.12.141-160

Majamaa, W., Junnila, S., Doloi, H. and Niemistö, E. (2008) End-user oriented public-private partnerships in real estate industry, International Journal of Strategic Property Management, 12(1), pp. 1-17. doi:10.3846/1648715X.2008.12.1-17

McDonald, S., Malys, N. and Malienè, V. (2009) Urban regeneration for sustainable communities: A case study, Technological and Economic Development of Economy, 15(1), pp. 49-59. doi:10.3846/1392-8619.2009.15.49-59

Mickaitytè, A., Zavadskas, E.K., Kaklauskas, A. and Tupenaitè, L. (2008) The concept model of sustainable buildings refurbishmen, International Journal of Strategic Property Management, 12(1), pp. 53-68. doi:10.3846/1648-715X.2008.12.53-68

Miller, C.J.M., Packham, G.A., Pickernell, D.G. and Mcgovern, M. (2004) Building for the future: The potential importance of the construction industry in Welsh economic development policy, Construction Management and Economics, 22(5), pp. 533-540. doi:10.1080/01446190310001649128 
Mitkus, S. (2004a) Statybos dalyviu rizika ir atsakomybė už statybos produktų defektus [Risk and liability of parties in the construction process for defects of construction products], Technological and Economic Development of Economy, 10(3), pp. 109-115.

Mitkus, S. (2004b) Rizikos dèl papildomu nenumatytu darbu atsiradimo paskirstymas statybos rangos sutartyse [Allocation of risk of additional unforeseen tasks in construction contracts], In proceedings "Business, management and education 2004", ISSN 1648-8156, pp. 108-118. (In Lithuanian)

Mitkus, S. (2005) Graphical risk and liability allocation models in construction contracts, Foundations of Civil and Environmental Engineering, 6, pp. 129-144.

Mitkus, S. (2007) Statybos teise 2007: norminiu teises aktu rinkinys/Antroji pataisyta ir papildyta laida [Construction law 2007: selection of normative legislation. The $2^{\text {nd }}$ amended and supplemented edition]. Vilnius: Eugrimas. (In Lithuanian)

Mitkus, S. and Šostak, O.R. (2008) Peculiarities of defence of public and private interests, Socialiniai tyrimai, 2(12), pp. 75-93.

Mitkus, S. and Šostak, O.R. (2008a) Modelling the process for defence of third party rights infringed while implementing construction investment projects, Technological and Economic Development of Economy, 14(2), pp. 208-223. doi:10.3846/1392-8619.2008.14.208-223

Petrovic, J., Ivkovic, I., Vujačic, I. and Žeželj, S. (2009) Possibilities of buses on alternative fuel in public urban transport in Belgrade, Technological and Economic Development of Economy, 15(1), pp. 78-89. doi:10.3846/1392-8619.2009.15.78-89

Petrušonis, V. (2004) Aukštybinès statybos reguliavimas mieste [Regulation of High-rise Building in Urban Areas], Town Planning and Architecture, 29(1), pp. 74-81. (In Lithuanian)

Poszyler-Adamska, A. and Czerniak, A. (2007) Biological and chemical indication of roadside ecotone zones, Journal of Environmental Engineering and Landscape Management, 15(2), pp. 113a-118a.

Ribeiro, F.L. (2008) Urban regeneration economics: The case of Lisbon's old downtown, International Journal of Strategic Property Management, 12(3), pp. 203-213. doi:10.3846/1648-715X.2008.12.203-213

Scherer, M., Wichser, J. and Venckauskaite, J. (2009) Alternatives to automated people-mover systems for small but dense populated areas,
Technological and Economic Development of Economy, 15(1), pp. 90-101.

doi:10.3846/1392-8619.2009.15.90-101

Smid, J.W. and Nieboer, N. (2008) Energy-efficient asset management for professional landlords, International Journal of Strategic Property Management, 12(1), pp. 19-34. doi:10.3846/1648-715X.2008.12.19-34

STR (2004) Statybos Techninis Reglamentas STR 2.02.01:2004 „Gyvenamieji pastatai“ [Construction Technical Regulation STR 2.02.01:2004 "Residential Buildings". Approved by the order No. 705 of 24/12/2003 of the Minister of Environment of the Republic of Lithuania], Vilnius, Valstybès žinios, 200402 12, Nr. 23-721. (In Lithuanian)

Šostak, O.R. and Kutut, V. (2009) Neteisètos statybu plètros tyrimas Kuršiu nèrijos nacionaliniame parke (Investigation into expansion of illegal construction in the national park of curonian spit), Business:Theory and Practice, 10(3), pp. 223-232.

doi:10.3846/1648-0627.2009.10.223-232

Štreimikiené, D. and Esekina, B. (2008) EU pollution reduction strategies and their impact on atmospheric emissions in Lithuania, Technological and Economic Development of Economy, 14(2), pp. 162-170.

doi:10.3846/1392-8619.2008.14.162-170

The Supreme Administrative Court of Lithuania (2004) Lietuvos vyriausiojo administracinio teismo $2004 \mathrm{~m}$. sausio $23 \mathrm{~d}$. nutartis administracinèje byloje visuomeninè organizacija „Žvèryno bendruomenë“ prieš Vilniaus m. savivaldybès administracijos miesto plètros departamenta, Nr. A-03-11-04 [The Judgement of the Supreme Administrative Court of Lithuania of 23 January 2004 in the administrative case The public organisation "Žvèryno Bendruomenè" vs. the Department for Urban Development of the Administration of Vilnius City Municipality, No. A-03-11-04]. [Online] The Supreme Administrative Court of Lithuania. Available at: http://www.lvat.lt/Default. aspx?item=nutart\&lang=1 [accessed 26 September 2007] (In Lithuanian)

The Supreme Administrative Court of Lithuania (2006a) Lietuvos vyriausiojo administracinio teismo $2006 \mathrm{~m}$. vasario $20 \mathrm{~d}$. sprendimas administracineje byloje pareiškejjai A. S., B. S. ir T. Z. prieš Vilniaus $\mathrm{m}$. savivaldybès administracija, Nr. A ${ }^{11-792 / 2006}$ [The resolution of the Supreme Administrative Court of Lithuania of 20 February 2006 in the administrative case the Applicants A. S., B. S. and T. Z. vs. the Ad- 
ministration of Vilnius City Municipality, No. $\mathrm{A}^{11}$-792/2006]. [Online] The Supreme Administrative Court of Lithuania. Available at: http:// www.lvat.lt/Default.aspx?item=nutart\&lang=1 [accessed 25 September 2007] (In Lithuanian)

The Supreme Administrative Court of Lithuania (2006b) Lietuvos vyriausiojo administracinio teismo $2006 \mathrm{~m}$. rugsejo $5 \mathrm{~d}$. nutartis administracineje byloje Kazokiškiu bendruomenè ir G.G. prieš Vilniaus m. RAAD [The judgement of the Supreme Administrative Court of Lithuania of 5 September 2006 in the administrative case The Community of Kazokiškès and G.G. vs. RAAD of the City of Vilnius]. [Online] The Supreme Administrative Court of Lithuania. Available at: http://www.lvat.lt/ Default.aspx?item $=$ nutart\&lang $=1$. [accessed 7 September 2007] (In Lithuanian)

The Supreme Administrative Court of Lithuania (2006c) Lietuvos vyriausiojo administracinio teismo $2006 \mathrm{~m}$. spalio $24 \mathrm{~d}$. nutartis administracinëje byloje Lampèdžiu bendruomenès centras prieš Kauno miesto savivaldybès administracija. Nr. A ${ }^{10}-1775-2006$ [The judgement of the Supreme Administrative Court of Lithuania of 24 October 2006 in the administrative case The Community Centre of Lampedžiai vs. the Administration of Kaunas City Municipality. No. $\mathrm{A}^{10}$-1775-2006]. [Online] The Supreme Administrative Court of Lithuania. Available at: http:// www.infolex.lt/praktika/tekstas.asp?id=71163 [accessed 28 November 2008] (In Lithuanian)

The Supreme Administrative Court of Lithuania (2007) Lietuvos vyriausiojo administracinio teismo $2007 \mathrm{~m}$. sausio $19 \mathrm{~d}$. nutartis administracinèje byloje pareiškejjai T. Z. prieš Vilniaus $\mathrm{m}$. savivaldybès administracija, Nr. $\mathrm{A}^{3}$-64-07 [The judgement of the Supreme Administrative Court of Lithuania of 19 January 2007 in the administrative case The Applicant T. Z. vs. the Administration of Vilnius City Municipality, No. A ${ }^{3}$-64-07]. [Online] The Supreme Administrative Court of Lithuania. Available at: http://www.lvat.lt/Default. aspx?item=nutart\&lang=1. [accessed 25 September 2007] (In Lithuanian)

Thematic Strategy on air pollution (2005) Communication from the Commission to the Council and the European Parliament - Thematic Strategy on air pollution \{SEC(2005) 1132\} \{SEC(2005) 1133\}. [Online] Commission of the European Communities. Available at: http:// eur-lex.europa.eu/LexUriServ/LexUriServ. do?uri=CELEX:52005DC0446:EN:NOT [accessed 13 February 2008]
Turskis, Z., Zavadskas, E.K. and Zagorskas, J. (2006) Sustainable city compactness evaluation on the basis of GIS and Bayes rule, International Journal of Strategic Property Management, 10(3), pp. 185-207.

UNECE (1998) UNECE Convention on Access to Information, Public Participation in Decisionmaking and Access to Justice in Environmental Matters. [Online] United Nations Economic Commission for Europe UNECE. Available at: http://www.unece.org/env/pp/documents/ cep43e.pdf [accessed 21 January 2007]

Urbanavičienè, V., Kaklauskas, A. and Zavadskas, E.K. (2009) The conceptual model of constructional and real estate negotiation, International Journal of Strategic Property Management, 13(1), pp. 53-70. doi:10.3846/1648-715X.2009.13.53-70

Vaišis, V. and Januševičius, T. (2008) Investigation and evaluation of noise level in the northern part of Klaipeda city, Journal of Environmental Engineering and Landscape Management, 16(2), pp. 89-96. doi:10.3846/1648-6897.2008.16.89-96

Vaitekūnas, P. and Banaitytè, R. (2007) Modelling of motor transport exhaust pollutant dispersion, Journal of Environmental Engineering and Landscape Management, 15(1), pp. 39-46.

Visuomenès dalyvavimo teritoriju planavimo procese nuostatai (2007) [The Regulations on Participation of the Society in the Territorial Planning Process], Vilnius, Valstybès žinios, 2007 03 20, Nr. 33-1190. (In Lithuanian)

Viteikiene, M. and Zavadskas, E.K. (2007) Evaluating the sustainability of Vilnius city residential areas, Journal of Civil Engineering and Management, 13(2), pp. 149-155.

Vrubliauskas, D. (2005) Miesto bendruomeniu vaidmuo tausojant istorinès aplinkos savitumą [The Role of Urban Communities in Preservation of Distinctive Features of Historical Environment], Town Planning and Architecture, 29(1), pp. 33-36. (In Lithuanian)

Vyzienè, R. and Girgždys, A. (2009) Investigation of aerosol number concentration in Jonava town, Journal of Environmental Engineering and Landscape Management, 17(1), pp. 51-59. doi:10.3846/1648-6897.2009.17.51-59

Wong, E.O.W. and Yip, R.C.P. (2004) Promoting sustainable construction waste management in Hong-Kong, Construction Management and Economics, 22(6), pp. 563-566. doi:10.1080/0144619042000226270 
Yu, W.D. and Lo, S.S. (2005) Time-dependent construction social costs model, Construction Management and Economics, 23(3), pp. 327-337. doi:10.1080/01446190500040281

Zavadskas, E.K., Kaklauskas, A., Vainiūnas, P. and Šaparauskas, J. (2004) A model of sustainable urban development formation, International Journal of Strategic Property Management, 8(4), pp. 219-229.
Zavadskas, E.K., Kaklauskas, A., Turskis, Z. and Kalibatas, D. (2009) An approach to multiattribute assessment of indoor environment before and after refurbishment of dwellings, Journal of Environmental Engineering and Landscape Management, 17(1), pp. 5-11. doi:10.3846/1648-6897.2009.17.5-11

\section{SANTRAUKA}

\section{SVEIKOS IR HARMONINGOS GYVENAMOSIOS IR DARBO APLINKOS IŠSAUGOJIMAS PLEČIANT MIESTUS}

\section{Sigitas MITKUS, Olga Regina ŠOSTAK}

Nagrinejjama, kaip tankinant urbanizuotu teritoriju užstatymą pabloginamos aplinkiniu namu gyventojų (trečiuju asmenu) gyvenimo salygos dèl neigiamo statybos poveikio vietinei aplinkai. Ypatingas dèmesys skiriamas esminių teisių pažeidimams nustatyti planuojant teritorijas, nes šie pažeidimai daro tiesioginę itaka sveikos ir harmoningos bei ir poilsio aplinkos praradimui ne tik tretiesiems asmenims, bet ir būsimiems naujai statomo namo gyventojams. Tam tikslui sudarytas esminių teisių pažeidimų planuojant teritorijas klasifikatorius. Išnagrinèta teismu praktika ir nustatyta, kas ir kokia apimtimi gali užginčyti administraciniu bylu teisenos i̇statymo nustatyta tvarka pažeidimus aplinkosaugos klausimais. Straipsnyje nagrinejamos trečiuju asmenu teisiu i sveiką ir harmoninga gyvenamają bei darbo aplinką išsaugojimo problemos vykdant statybas urbanizuotose teritorijose. Išnagrinèta Lietuvos Respublikos trečiuju asmenu teisiu i sveiką ir harmoningą gyvenamają bei darbo aplinka gynimo teismu praktika, aptartas viešojo ir privataus intereso santykis šioje srityje. Nustatyti pagrindiniai galimi pažeidimai planuojant statybas, sudarytas šių pažeidimu klasifikatorius. 